\title{
PERILAKU PETANI ANGGOTA PERKUMPULAN PETANI PEMAKAI AIR (P3A) RUKUN SANTOSO DI DESA KONAROM BARAT KECAMATAN DUMOGA TENGGARA
}

\author{
Suseno \\ Theodora M. Katiandagho \\ Wilson M. Wangke
}

\begin{abstract}
The aim of research is to describe the Rukun Santoso water user associations (P3A) Konarom West Village, District Southeast Dumoga and analyze behaviour of its members. The collection of data was carried out for five months, from January until May 2015. The primary data collected through face to face interviews. Respondents was selected for 30 respondents by using random sampling mechanism. The interviews was conducted based on questionnaires that have prepared before. The secondary data was obtained through agencies that related to this research topic. The data analysis is descriptive. The results showed that knowledge of water user farmer groups in the organization is very good and then supported by the attitude of members of water user farmers is positive in favor of any program that is planned and the action of water user farmer association is good enough so that each program can run as expected.
\end{abstract}

Keywords: knowledge, attitude, action, Rukun Santoso, Southeast Dumoga

\section{ABSTRAK}

Tujuan penelitian yaitu mendeskripsikan Perkumpulan Petani Pemakai Air (P3A) Rukun Santoso dan menganalisis Perilaku Petani dari Anggota Perkumpulan Petani Pemakai Air (P3A) Rukun Santoso di Desa Konarom Barat, Kecamatan Dumoga Tenggara. Pengumpulan data dilakukan selama lima bulan, sejak bulan Januari hingga bulan Mei 2015. Data primer diperoleh secara langsung melalui wawancara berdasarkan kuesioner yang telah dipersiapkan sebelumnya. Kemudian data sekunder diperoleh melalui instansi-instansi terkait dengan judul penelitian ini. Pengambilan sampel di-lakukan dengan teknik random sampling dengan responden sebanyak 30 responden. Analisis yang digunakan yaitu secara deskriptif. Hasil penelitian menunjukkan bahwa pengetahuan kelompok petani pemakai air dalam berorganisasi sangatlah baik kemudian ditunjang dengan sikap anggota petani pemakai air adalah positif dalam mendukung setiap program yang direncanakan dan tindakan perkumpulan petani pemakai air cukup baik sehingga setiap program dapat berjalan sesuai yang diharapkan.

Kata Kunci:pengetahuan, sikap, tindakan, Rukun Santoso, Dumoga Tenggara

\section{PENDAHULUAN}

\section{Latarbelakang}

Pemanfaatan sumber daya air dapat dilakukan hampir pada semua aspek kehidupan manusia baik untuk kebutuhan hidup sehari-hari maupun untuk usaha yang menggunakan bahan dasar air. Pasal 8 UU No. 1.Tahun 1960 tentang peraturan dasar pokok-pokok agraria (UUPA) menyatakan pengambilan kekayaan alam, termasuk air, harus diatur dengan perundang-undangan. Pasal 41 No. 7 Tahun 2004 tentang Sumber Daya Air (UUSDA) disebutkan bahwa pemenuhan air baku untuk pertanian dilakukan dengan pengembangan sistem irigasi.

Pengembangan pedesaan menjadi prioritas utama dalam pembangunan. Untuk menurunkan 
kemiskinan di pedesaan menitikberatkan pada pertumbuhan pertanian. Untuk mewujudkannya perlu perbaikan kinerja irigasi, pemeliharaan jaringan irigasi dan pengelolaan pemeliharaan jaringan irigasi berfungsi dengan baik, maka pemakaian air yang optimal di daerah irigasi dapat tercapai dengan baik.

Salah satu desa yang sedang melakukan upaya pembangunan adalah Desa Konarom Barat. Desa ini terletak di Kecamatan Dumoga Tenggara Kabupaten Bolaang Mongondow. Desa ini merupakan hasil pemekaran. Walaupun desanya adalah desa yang baru mengalami pemekaran namun petani yang ada di desa ini sudah bisa dikatakan petani yang maju. Dikatakan petani maju karena rata-rata petani disini sudah mampu meng-optimalkan sistem jaringan irigasi yang ada. Dalam menjaga dan memelihara sistem jaringan irigasinya petani Desa Konarom Barat ini membentuk sebuah perkumpulan petani pemakai air yang lazim di kenal dengan sebutan P3A. P3A inilah yang tugasnya mengatur setiap kegiatan yang berkaitan dengan penggunaan air yang ada.

Dari adanya pembentukan P3A petani yang ada di Desa Konarom Barat semakin menunjukan kemajuan di tingkat penghasilan maupun di tingkat kerukunannya. Dahulunya, petani disini adalah petani dalam kategori petani kurang mampu, tapi sejak dibangunya irigasi Sekunder oleh pemerintah lambat laun petani desa Konarom Barat mengalami kemajuan bukan hanya dari penghasilan tetapi dari pola bercocok tanam dan cara berorganisasinya.

Dengan demikian, petani berkesempatan untuk menumbuhkan kelembagaan pengelola irigasi. Sarana fisik sebuah jaringan irigasi merupakan perangkat kerasnya, dan lembaga formal maupun tidak formal merupakan perangkat lunaknya. Lembaga-lembaga yang telah dikembangkan oleh petani itu merupakan sumber daya nasional yang patut dipelajari dan dipahami agar potensi air irigasi pedesaan dapat terus ditingkatkan.

\section{Konsep Perilaku}

Perilaku manusia merupakan hasil daripada segala macam pengalaman serta interaksi manusia dengan lingkungannya yang terwujud dalam bentuk pengetahuan, sikap dan tindakan. Dengan kata lain, perilaku merupakan respon/reaksi seorang individu terhadap stimulus yang berasal dari luar maupun dari dalam dirinya. Respon ini dapat bersifat pasif (tanpa tindakan: berpikir, berpendapat, bersikap) maupun aktif (melakukan tindakan). Sesuai dengan batasan ini, perilaku kesehatan dapat dirumuskan sebagai bentuk pengalaman dan interaksi individu dengan lingkungannya, khususnya yang menyangkut pengetahuan dan sikap tentang kesehatan. Beberapa ahli membedakan bentukbentuk perilaku ke dalam tiga domain yaitu pengetahuan, sikap, dan tindakan (Sarwono, 2001).

Adapun bentuk-bentuk dari perilaku dibedakan menjadi 3 bagian, yaitu:

\section{Pengetahuan}

Menurut Notoatmodjo, (2005) Pengetahuan adalah hasil penginderaan manusia, atau hasil tahu seseorang terhadap objek melalui indera yang dimiliki (mata, hidung, telinga, dan sebagainya). Dengan sendirinya, pada waktu penginderaan sampai menghasilkan pengetahuan tersebut sangat dipengaruhi intensitas perhatian dan persepsi terhadap objek. Sebagian besar pengetahuan seseorang dipengaruhi indera pendengaran (telinga), dan indera pengelihatan (mata).

Sikap

Para ahli dalam memberikan definisi tentang sikap banyak terjadi perbedaan. Terjadinya hal ini karena sudut pandang yang berbeda tentang sikap itu sendiri. Sikap pada awalnya diartikan sebagai suatu syarat untuk munculnya suatu tindakan. Konsep itu kemudian berkembang semakin luas dan digunakan untuk menggambarkan adanya suatu niat yang khusus atau umum, berkaitan dengan kontrol terhadap respon pada keadaan tertentu (El-mubarok, 2009).

\section{Tindakan}

Setelah seseorang mengetahui stimulus, kemudian mengadakan penelitian atau pendapat apa yang telah diketahui untuk dilaksanakan atau di- 
praktekan. Suatu sikap belum otomatis terwujud dalam suatu tindakan. Agar terwujud sikap menjadi suatu perbuatan nyata diperlukan faktor pendukung berupa fasilitas dan dukungan dari pihak lain. Tindakan terdiri dari beberapa tingkat yaiti:

a. Persepsi

Mekanisme mengenal dan memilih berbagi objek sehubungan dengan tindakan yang akan diambil.

b. Respon Terpimpin

Dapat melakukan sesuatu sesuai dengan urutan yang benar dan sesuai dengan contoh.

c. Mekanisme

Dapat melakukan sesuatu secara otomatis tanpa menunggu perintah atau ajakan orang lain.

d. Adopsi

Suatu tindakan yang sudah berkembang dengan baik, artinya tindakan itu dimodifikasi tanpa mengurangi kebenaran dari tindakan tersebut (Notoadmodjo, 2007).

\section{Pengertian Petani}

Peraturan Menteri Pertanian (Permentan) No. 273 Tahun 2007 tentang Pedoman Pembinaan Kelembagaan Petani menyebutkan bahwa kelompok tani adalah kumpulan petani/peternak/ pekebun yang dibentuk atas dasar kesamaan kepentingan, kesamaan kondisi lingkungan (sosial, ekonomi, sumberdaya) dan keakraban untuk meningkatkan dan mengembangkan usaha tani anggota.

Petani adalah orang yang pekerjaannya bercocok tanam pada tanah pertanian. Definisi petani menurut (Anwar, 1991) mengemukakan bahwa petani adalah orang yang melakukan cocok tanam dari lahan pertaniannya atau memelihara ternak dengan tujuan untuk memperoleh kehidupan dari kegiatan itu.

\section{Perkumpulan Petani Pemakai Air (P3A)}

Pengertian perkumpulan petani pemakai air adalah kelembagaan pengelolaan irigasi yang menjadi wadah petani pemakai air dalam suatu pelayanan irigasi yang dibentuk oleh petani pemakai air itu sendiri secara demokratis. Perkumpulan petani pemakai air merupakan organisasi sosial dari petani yang tidak berinduk pada golongan maupun partai politik, tetapi organisasi yang bergerak di bidang pertanian, dalam kegiatan pengelolaan air sehubungan dengan kepentingan pelaksanaan usahatani.

Wadah Perkumpulan Petani Pemakai Air merupakan himpunan bagi petani pemakai air yang bersifat sosial-ekonomi, budaya, dan berwawasan lingkungan. P3A dibentuk dari, oleh, dan untuk petani pemakai air secara demokratis, yang pengurus dan anggotanya terdiri dari unsur petani pemakai air. P3A dalam satu daerah pelayanan sekunder tertentu dapat bergabung sampai terbentuk Gabungan Perkumpulan Petani Pemakai Air (GP3A). GP3A dalam satu daerah irigasi tertentu dapat bergabung sampai terbentuk Induk P3A (Ikatan Petani Pemakai Air atau IP3A) (Annonimus, 2010).

Peraturan Pemerintahan Nomor 77 Tahun 2001 Pasal 4 tentang Irigasi, menjelaskan bahwa pengelolaan irigasi diselenggarakan dengan mengutamakan kepentingan masyarakat petani dan dengan menempatkan perkumpulan petani pemakai air sebagai pengambilan keputusan dan pelaku utama dalam pengelolaan irigasi yang menjadi tanggung jawabnya (Isnaini, 2006).

\section{METODOLOGI PENELITIAN}

\section{Waktu Penelitian dan Tempat}

Penelitian ini berlangsung selama Enam bulan sejak bulan Januari sampai Juni 2015, sejak persiapan hingga penyusunan laporan hasil penelitian. Tempat penelitian di Desa Konarom Barat Kecamatan Dumoga Tenggara.

\section{Metode Pengumpulan Data}

Adapun data yang dikumpulkan dalam penelitian ini adalah berupa data primer dan data sekunder. Data primer merupakan data yang diperoleh dari hasil wawancara langsung dengan responden elalui kuisioner yang telah disiapkan. Data sekunder, merupakan data yang diperoleh dari Kantor Kelurahan dan Kantor Kecamatan Setempat. 


\section{Konsep dan Pengukuran Variabel}

1. Karakteristik Petani Anggota Perkumpulan Petani Pemakai Air Rukun Santoso.

2. Perilaku manusia merupakan hasil daripada segala macam pengalaman serta interaksi manusia dengan lingkungannya yang terwujud dalam bentuk. Perilaku dijelaskan dalam tiga bagian seperti di bawah ini.

a. Sikap petani anggota merupakan dorongan yang berasal dari diri anggota perkumpulan petani pemakai air dari reaksi terhadap stimulus yang menghasilkan pengaruh dan penolakan, positif dan negatif terhadap organisasi P3A, di Desa Konarom Barat Kecamatan Dumoga Tenggara.

1) Sikap Positif adalah kecenderungan untuk menyenangi, mendekati atau bahkan menginginkan kehadiran objek tertentu.

2) Sikap Negatif adalah Kecenderungan untuk menjauhi, membenci, menghindar atau tidak menyukai kehadiran objek tertentu.

Dalam pengukuran sikap didapatkan beberapa kategori positif dan negatif. Kategori sikap dapat diukur berdasarkan tabel 1 :

Tabel 1 Kategori sikap

\begin{tabular}{cc}
\hline Kategori & Sikap \\
\hline $1-10$ & Respon Negatif \\
$11-20$ & Respon Cukup \\
\hline $21-30$ & Respon Positif
\end{tabular}

b. Pengetahuan merupakan sampai mana tingkat pengetahuan anggota P3A dalam mengelola saluran irigasi di Desa Konarom Barat Kecamatan Dumoga Tenggara. Pengetahuan yang di ukur dalam penelitian ini merupakan pengetahuan dasar yang dimiliki anggota kelompok perkumpulan petani pemakai air dalam bercocok tani dan berorganisasi. Pengetahuan itu yang di ukur yaitu:

$\begin{array}{ll}1 & \text { Pengolahan Lahan } \\ 2 & \text { Pembibitan } \\ 3 & \text { Memindahkan Bibit Tanaman } \\ 4 & \text { Penanaman } \\ 5 & \text { Merawat Tanaman } \\ 6 & \text { Panen } \\ 7 & \text { Mengelola Jaringan Irigasi } \\ 8 & \text { Mengelola Keuangan } \\ 9 & \text { Agenda Rapat } \\ 10 & \text { Pembagian Jadwal }\end{array}$

c. Tindakan merupakan suatu kegiatan yang dilakukan oleh anggota P3A dalam melaksanakan atau menjalankan program yang sudah direncanakan. Tindakan yang diukur dalam penelitian ini yaitu tindakan anggota kelompok tani dalam mengikuti setiap program yang dilaksanakan oleh perkumpulan petani pemakai air.Tindakan yang dimaksud adalah seperti dibawah ini:

$\begin{array}{ll}1 & \text { Pengelolaan saluran irigasi } \\ 2 & \text { Mengontrol saluran irigasi } \\ 3 & \text { Melakukan perbaikan irigasi } \\ 4 & \text { Pembagian jadwal air } \\ 5 & \text { Keikutsertaan rapat } \\ 6 & \text { Pelaksanaan jadwal } \\ 7 & \begin{array}{l}\text { Melakukan evaluasi terhadap kegiatan yang } \\ \text { di lakukan }\end{array} \\ 8 & \text { Pembayaran iuran } \\ 9 & \text { Gotong royong } \\ 10 & \begin{array}{l}\text { Melakukan evaluasi terhadap pengawasan } \\ \text { kegiatan }\end{array}\end{array}$

\section{Metode Pengambilan Sampel}

Pengambilan sampel dilakukan dengan cara Random Sampling, yaitu sebanyak 30 Sampel dari 57 Anggota Perkumpulan Petani Pemakai Air (P3A) Rukun Santoso, Desa Konarom Barat. Alasan pengambilan sampel 30, karena dalam penentuan jumlah sampel terdapat sampel besar dan 
sampel kecil. pada sampel kecil jumlah sampel minimum adalah 30 sampel (responden).

\section{Metode Deskriptif}

Analisis deskriptif merupakan analisis data yang berupa identitas responden dan Perilaku Petani Anggota Perkumpulan Petani Pemakai Air (P3A). Rukun Santoso Desa Konarom Barat. Analisis ini dikelompokkan berdasarkan jawaban jawaban yang sama, kemudian dipersentasikan berdasarkan jumlah responden. Persentase yang terbesar merupakam faktor yang dominan dari masing-masing variable yang diteliti. Analisis ini merupakan kegiatan mengumpulkan, mengolah, dan kemudian mendeskripsikan atau menggambarkan data yang telah terkumpul sebagaimana adanya tanpa bermaksud membuat kesimpulan yang berlaku untuk umum atau generalisasi (Sugiyono 2009).

\section{Metode Analisis Data}

Untuk menganalisis identifikasi masalah 1) menggunakan analisis deskriptif yaitu dengan melihat Perilaku Petani Anggota Perkumpulan Petani Pemakai Air (P3A) Rukun Santoso di Desa Konarom Barat Kecamatan Dumoga Tenggara. Untuk menganalisis identifikasi masalah. 2) menggunakan teknik pengskalaan lingkert, yaitu mengelompokkan variabel dengan menjumlahkan skor dari nilai seperangkat variabel yang bersangkutan berupa pernyataan positif dan pernyataan negatif. Untuk menganalisis identifikasi masalah 3) mengetahui bagaimana tindakan Petani Anggota Perkumpulan Petani Pemakai Air (P3A) Rukun Santoso di Desa Konarom Barat Kecamatan Dumoga Tenggara diselesaikan dengan metode analisis teknik skoring.

\section{HASIL DAN PEMBAHASAN}

\section{Pengetahuan}

Pengetahuan anggota kelompok perkumpulan petani pemakai air terhadap kegiatan dan program yang di jalankan oleh perkumpulan petani pemakai air tersebut dapat diukur berdasarkan persentase skor yang diperoleh atas jawaban-jawaban responden terhadap kuisioner yang telah disebarkan. dalam pengetahuan dapat dikategorikan dalam beberapa kategori seperti Tabel 2 di bawah ini :

Tabel 2. Keterangan Nilai Pada Skor

\begin{tabular}{cl}
\hline Skor & \multicolumn{1}{c}{ Keterangan } \\
\hline $1-10$ & Pengetahuan kurang \\
$11-20$ & Pengetahuan cukup baik \\
$21-30$ & Pengetahuan baik \\
\hline
\end{tabular}

Komponen-komponen yang diukur dalam pengetahuan petani dapat dilihat pada tabel 3 disini dijelaskan beberapa komponen yang akan diukur :

Hal ini menunjukkan bahwa pengetahuan anggota kelompok perkumpulan petani pemakai air dapat dikatakan baik dan mengerti setiap tugas dan kewajiban yang dibebankan kepada mereka. Pada tabel 3. Diperoleh nilai 21,5 dengan persentase 71,64 Persen yang dimana nilai tersebut dalam kategori pengetahuan yang dimiliki adalah baik. Jika pengetahuan akan program yang dijalankan adalah baik maka otomatis kedepannya dalam kegiatan pelaksanaannya tidak akan mengalami hambatan yang berat. 
Tabel 3.Pengetahuan Responden Petani Anggota Perkumpulan Petani Pemakai Air (P3A) Rukun Santoso

\begin{tabular}{llccc}
\hline No & Uraian & $\begin{array}{l}\text { Skor yang diharap- } \\
\text { kan }\end{array}$ & $\begin{array}{c}\text { Skor yang di- } \\
\text { peroleh }\end{array}$ & Persentase\% \\
\hline 1 & Cara pengolahan lahan & 3 & 2,5 & 8,33 \\
2 & Cara pembibitan & 3 & 2 & 6,66 \\
3 & Cara memindahkan bibit tanaman & 3 & 2,5 & 8,33 \\
4 & Cara penanaman & 3 & 2,5 & 8,33 \\
5 & Cara merawat tanaman & 3 & 3 & 10,00 \\
6 & Cara panen & 3 & 2 & 6,66 \\
7 & Cara mengelola jaringan irigasi & 3 & 2,5 & 8,33 \\
8 & Cara mengelola keuangan & 3 & 1,5 & 5,00 \\
9 & Cara agenda rapat & 3 & 1,5 & 5,00 \\
10 & Cara pembagian jadwal & 3 & 1,5 & 5,00 \\
\hline & Jumlah & 30 & 21,5 & 71,64 \\
\hline
\end{tabular}

Sumber : Diolah Dari Data Primer 2014

\section{Sikap Petani Anggota Terhadap Kinerja dan Kegiatan P3A Rukun Santoso Di Desa Konarom Barat}

Sikap dan presepsi dari petani anggota P3A sangatlah berbeda-beda walaupun mereka berada dalam satu keanggotaan. Untuk melihat bagaimana sikap petani anggota P3A maka patut diketahui apakah perkumpulan ini layak untuk diteruskan dan apakah setiap kegiatan yang dilakukannya disukai oleh ketua P3A.

Sikap petani anggota Perkumpulan Petani Pemakai Air (P3A) yang selama ini membantu petani dapat diketahui dengan melihat jawaban jawaban petani anggota responden terhadap kuesioner yang berisi pernyataan - pernyataan yang diberikan.

Untuk pernyataan positif jawaban

a. Sangat Tidak Setuju (STS) diberi nilai 1.

b. Tidak Setuju (TS) diberi nilai 2.

c. Ragu ragu (R) diberi nilai 3.

d. Setuju (S) diberi nilai 4, dan

e. Sangat Setuju (SS) diberi nilai 5.

Demikian juga sebaliknya untuk pernyataan negatif, jawaban

a. Sangat Tidak Setuju (STS) diberi nilai 5,

b. Tidak Setuju (TS) diberi nilai 4, c. Ragu ragu (R) diberi nilai 3,

d. Setuju (S) diberi nilai 2, dan

e. Sangat Setuju (SS) diberi nilai 1.

Sikap P3A dapat dikategorikan dalam beberapa kategori-kategori tersebut dapat dilakukan seperti di bawah ini:

\begin{tabular}{cc}
\hline Kategori & Sikap \\
\hline $1-10$ & Respon Negatif \\
$11-20$ & Respon Cukup \\
$21-30$ & Respon Positif \\
\hline
\end{tabular}

Dari setiap jawaban pernyataan akan diperoleh distribusi frekuensi responden bagi setiap kategori kemudian secara kumulatif dilihat adanya perbedaan-perbedaan yang nyata, sehingga diperoleh skor (nilai skala untuk masing-masing kategori jawaban), kemudian skor terhadap masing masing pernyataan dijumlahkan.

Pertanyan-pertanyaan yang di ajukan kepada responden untuk mengetahui Sikap petani anggota Perkumpulan Petani Pemakai Air (P3A) Rukun Santoso, dapat dijelaskan seperti dibawah ini.

1. Susunan Program. Susunan program adalah salah satu pertanyaan yang di ajukan kepada responden untuk mengetahui bagaimana sikap responden terhadap susunan program yang disusun oleh pengurus. Berdasarkan hasil wa- 
wancara dengan responden hasil yang di peroleh sebanyak 27 orang menyukai susunan yang telah dibuat sedangkan yang tidak menyukainya hanya 3 orang saja.

2. Cara pemilihan pengurus. Pemilihan pengurus merupakan hal yang selalu menjadi hal utama dalam pengurusan. Hasil penelitian yang dilakukanpun menunjukan bahwa masih banyak responden yang tidak menyukai cara pemilihan pengurus. Responden yang menyukai hanya sebesar 14 saja sedangkan 16 orang tidak menyukai dengan cara yang dilakukan dalam memilih pengurus.

3. Agenda rapat. Berdasarkan wawancara yang dilakukan oleh responden maka hasil yang didapatkan terhadap pertanyaan bagaimanakah agenda rapat yang dilakukan apakah responden setuju atau tidak yaitu sebanyak 28 responden setuju dan 2 orang yang tidak setuju.

4. Penjadwalan air irigasi. Berdasarkan hasil yang diperoleh sebanyak 27 responden setuju dengan system penjadwalan yang dilakukan sedangkan sisanya 3 responden tidak menyukai.

5. Program P3A. berdasarkan hasil wawancara ternyata masih ada responden yang tidak menyukai program P3A yang telah disusun yaitu sebanyak 6 orang dan yang setuju sebanyak 24 responden.

6. Iuran. Dalam pembayaran iuran dan besaranya dibayarkan ternyata seluruh responden setuju dengan iuran yang telah ditetapkan.

Berdasarkan uaraian-uraian diatas didapatkan hasil nilai yang setuju sebanyak 150 sedangkan yang tidak nilainya 30 . Kemudian hasil itu dirata-ratakan berdasarkan jumlah pertanyaan yang diajukan dengan hasil rata-rata responden yang setuju sebanyak 25 orang dan tidak setuju 5 orang.penjelasan sikap responden tersebut dijelaskan dengan pada Tabel 4.
Tabel 4. Sikap Petani Anggota Perkumpulan Petani Pemakai Air (P3A) Rukun Santoso Di Desa Konarom Barat

\begin{tabular}{lcc}
\hline Kategori & $\begin{array}{c}\text { Jumlah } \\
\text { (orang) }\end{array}$ & Persentase \% \\
\hline Positif & 25 & 83,00 \\
Negatif & 5 & 17,00 \\
\hline Total & 30 & 100,00
\end{tabular}

Sumber : Diolah Dari Data Primer 2014

Hal ini menyatakan bahwa perilaku anggota Perkumpulan Petani Pemakai Air (P3A) Rukun Santoso di Desa Konarom Barat baik, karena 83 Persen berdampak positif bagi petani dan sesuai dengan kebutuhan petani dalam irigasi usahatani. Selain itu, petani juga menilai kegiatan atau program yang diterapkan oleh Perkumpulan Petani Pemakai Air (P3A) sangat berguna bagi petani untuk memudahkan irigasi.

Sehingga petani anggota P3A hanya mengikuti program yang telah ditetapkan oleh pengurus dan kemudian membayar iuran yang menjadi kewajiban mereka. Jika respon dari ketua sendiri itu sudah positif maka kehadiran dari P3A ini sangatlah membantu menyelesaikan masalah-masalah yang menyangkut tentang susahnya mendapatkan air yang cukup, guna pertumbuhan tanaman padi.

\section{Tindakan Petani Anggota Perkumpulan Petani Pemakai Air (P3A) Rukun Santoso.}

Tindakan adalah sebuah perilaku yang dilakukan oleh anggota kelompok dimana apakah mereka antusias dalam berpartisipasi untuk setiap kegiatan yang dilaksanan oleh perkumpulan petani pemakai air itu sendiri.Tindakan anggota perkumpulan petani pemakai air dapat dilihat berdasarkan tindakan yang dilakukan oleh petani itu sendiri. Tindakan yang dilakukan dapat dilihat seperti dibawah ini :

a. Bertani Sesuai Jadwal Air. Tindakan petani dalam bertani sesuai jadwal air dapat dilihat 
apakah petani mengikuti aturan yang telah dianjurkan berdasarkan jadwal air yang telah berlaku ataupun mereka bercocok tanam tidak mengikuti jadwal air. Berdasarkan hasil penelitian yang dilakukan didapatkan tindakan petani dalam mengikuti aturan bertani sesuai jadwal air sangatlah antusias dan merespon terhadap aturan tersebut.

b. Pengelolaan jaringan irigasi. Tindakan petani dalam ikut pengelolaan jaringan irigasi sangatlah membantu dan antusias karena mereka juga ingin mudah dalam mendapatkan air. Sehingga mereka sangat antusias dalam memelihara jaringan irigasi agar mereka mudah dalam mendapatkan air guna bercocok tanam.

c. Membayar iuran. Dalam membayar iuran sikap dan tindakan petani sudah dijelaskan dalam sikap positif responden bahwa seluruh responden setuju dalam pembayaran iuran. Jadi tindakannya sangat antusias dalam membayar iuran.

d. Taat kepada aturan. Sikap petani atau tindakan petani dalam menaati aturan yang telah dibuat sangatlah antusias dan jarang untuk melanggar aturan sehingga dapat dikatakan mereka sangatlah taat aturan.

\section{Tabel 5.Tindakan Petani Anggota Perkumpulan Petani Pemakai Air (P3A) Rukun Santoso}

\begin{tabular}{clccc}
\hline No & \multicolumn{1}{c}{ Uraian } & Skor yang diharapkan & Skor yang diperoleh & Persentase $\%$ \\
\hline 1 & Pengelolaan saluran irigasi & 3 & 2 & 6,66 \\
2 & Mengontrol saluran irigasi & 3 & 1,5 & 5,00 \\
3 & Melakukan perbaikan irigasi & 3 & 2 & 6,66 \\
4 & Pembagian jadwal air & 3 & 2 & 6,66 \\
5 & Keikut sertaan rapat & 3 & 1,5 & 5,00 \\
6 & Pelaksanaan jadwal & 3 & 1,5 & 5,00 \\
7 & Melakukan evaluasi terhadap & 3 & 3 & 10,00 \\
& kegiatan yang di lakukan & 3 & 3 & 10,00 \\
8 & Pembayaran iuran & 3 & 2,5 & 8,33 \\
9 & Gotong royong & 3 & 3 & 10,00 \\
10 & Melakukan evaluasi terhadap & 30 & 22 & 73,31
\end{tabular}

Sumber : Diolah Dari Data Primer 2014

Sedangkan tindakan yang lain dapat dilihat berdasarkan presentase dari partisipasi anggotanya. Komponen yang diukur dapat dijelaskan dengan tabel 5.

Tabel 5 menjelaskan bahwa skor yang diperoleh terhadap partisipasi atau tindakan yang dilakukan oleh anggota perkumpulan petani pemakai air yaitu 22 dengan presentase sebesar 73,31 Persen. Dengan kategori skor sebagai berikut, dilihat pada Tabel 6 .
Tabel 6. Keterangan Nilai Pada skor

\begin{tabular}{cl}
\hline Skor & \multicolumn{1}{c}{ Keterangan } \\
\hline $1-10$ & Tindakan kurang \\
$11-20$ & Tindakan cukup baik \\
$21-30$ & Tindakan baik \\
\hline
\end{tabular}

Hal ini menyatakan bahwa tindakan yang dilakukan oleh anggota perkumpulan petani pemakai air yaitu tindakannya cukup baik dengan skor yang didapatkan yaitu 22 dengan presentase 73,31 Per- 
sen. Dengan kategori tindakan baik maka dapat disimpulkan bahwa setiap program yang dilaksanakan oleh perkumpulan petani mendapat respon yang positif dan partisipasinya cukup baik.

\section{KESIMPULAN DAN SARAN}

\section{Kesimpulan}

Pengetahuan dari anggota kelompok petani pemakai air dalam berorganisasi atau tentang perkumpulan petani pemakai air apa yang menjadi tugas dan kewajiban dari anggota adalah baik dengan persentase 71,64 Persen. Sehingga anggota perkumpulan petani di Desa Konarom Barat cukup paham akan organisasi yang mereka ikuti. Pengetahuan yang baik akan memudahkan suatu perkumpulan organisasi yang cepat berkembang.

Sikap anggota perkumpulan petani pemakai air adalah positif yaitu 83 Persen sehingga dapat dikatakan bahwa kehadiran Perkumpulan petani pemakai air sangat dibutuhkan di Desa Konarom Barat untuk menunjang kemajuan dan memperbaiki pendapatan petani.

Tindakan yang dilakukan oleh anggota perkumpulan petani pemakai air adalah cukup baik dengan persentase 73,31 Persen. Sehingga setiap rencana atau program yang sudah direncanakan dapat berjalan sesuai yang diharapkan.

\section{Saran}

Peneliti berharap adanya peningkatan peran pemerintah untuk membina dan meningkatkan kemampuan serta tindakan anggota Perkumpulan petani pemakai air agar perkumpulan petani pemakai air yang ada di Konarom Barat dapat memaksimalkan Sumber Daya Manusia (SDM) secara maksimal. Selain itu diharapkan pemerintah memberi bimbingan dan membantu pendanaan untuk mengembangkan agar hasilnya memuaskan dan dapat memperbaiki pendapatan petani.

\section{Daftar Pustaka}

Adiwilaga, A. 1992. Pengantar Ilmu Pertanian, Rineka Cipta, Jakarta.
Ambler, 1992. Irigasi Di Indonesia. Dinamika Kelembagaan. LP3ES, Jakarta.

Annonimus, 2010. http://www. Stegoarchieve.Com/ Histori Diakses Hari Sabtu 25 April 2015 Jam $20: 30$.

Anwar, 1991. Evaluasi Kinerja Sumber Daya Manusia. Pt. Refisi Aditama, Bandung.

El-mubarok, Z. 2009. Membumikan Pendidikan Nilai, Mengumpulkan yang Terserak Menyambung yang Terputus dan Menyatukan yang Tercerai. Alvabeta CV, Bandung.

Isnaini, 2006. Pertanian Organik. Yogyakarta: Kreasi Wacana.

Kartasapoetra Dan Mulyani Sutedjo, 1994. Teknologi Pengairan. Jakarta: Bumi Aksara.

Notoatmodjo, 2007. Promosi Kesehatan dan Ilmu Kebidanan. Jakarta: Rineka Cipta.

2005. Pendidikan dan Perilaku Kesehatan. Jakarta: Rineka Cipta. ,2003. Pendidikan dan Prilaku

Kesehatan. Jakarta: Rineka Cipta.

Nurjayanti, 2013. Peran Paguyuban Sangkan Paraning Dumadi Terhadap Perubahan Perilaku Ekonomi Komunitas. Jurnal Universitas Negeri Semarang. Semarang.

Peraturan Menteri Pertanian , No. 273 Tahun 2007 Tentang Pedoman Pembinaan Kelembagaan Petani.

Peraturan Pemerintahan Nomor 77 Tahun 2001 Pasal 4 Tentang Irigasi.

Santosa. 2008. Perilaku Petani Padi Sawah Terhadap Penerapan Program Sekolah Lapang Pengelolaan Tanaman Terpadu (SL-PTT) di Kelurahan Tosuraya Selatan Kecamatan Ratahan Kabupaten Minahasa Tenggara. Skripsi. Fakutas Pertanian Universitas Sam Ratulangi. Manado.

Sarwono. 2001. Teori-Teori Psikologi Sosial. Raja Grafindo Persada, Jakarta.

Sunaryo. 2004. Psikologi Keperawatan. Jakarta: EGC.

Wahyuni, 1999. Partisi Petani dalam Rehabilitasi Irigasi Kecil. Padang: Pusat Studi Irigasi UNAND. Padang

Wawan, A Dan Dewi, M. 2010. Teori dan Pengukuran Pengetahuan, Sikap dan Prilaku Manusia. Nuha Medika, Yogyakarta.

Wibisono. 2011. Manajemen Kinerja Korporasi dan Organisasi”, Penerbit Erlangga, Jakarta. 